\title{
ALAIN DELON AS PROTAGONIST OF THE BEGINNING OF THE END
}

\author{
Simber Atay \\ Dokuz Eylül University, \\ Izmir, Turkey
}

\begin{abstract}
:
The beginning of the end is a special category of beginning. The beginning of the end is a dramatic / pathetic / romantic / existential process in general. Within this process, the beginning becomes the end, and the end becomes the beginning. Sometimes it has a slow rhythm, sometimes it is experienced with a breathless speed. Coincidences shape this process, at the same time, intuition plays a crucial role in defining it. Beginning of the end can be experienced socially or individually. Like the historical / mass / chaotic beginnings of the end, there are also individuals who represent beginning of the end within rebellion / sacrifice / victimization or auto-destruction acts. The beginning of the end is sometimes a relative emancipation process. Paradoxically, fear and courage, violence and humanistic principles are intertwined. It's also a perfect theme for artistic inspiration and creativity. Historically, there have been many "beginning of the end" periods. However, the period between the fall of the Austro-Hungarian Empire and Auschwitz is particularly important, and this topic is the subject of this article. In this context, Joseph Roth, Roman Vishniac, László Nemes, Joseph Losey, Alain Delon are some representatives of this topic in their respective fields with their works. In this paper, the phenomenon of "the beginning of the end" and its features will be developed using descriptive method.
\end{abstract}

Keywords: the beginning of the end, intuition, Joseph Roth, Roman Vishniac, László Nemes Alain Delon, Mr. Klein

\section{Introduction}

The first person to use the expression "the beginning of the end" is the French statesman and diplomat Talleyrand; and this expression has become a popular motto over time. Throughout history, there are many beginnings of the end. In this context, the general features of "the beginning of the end" phenomenon as real and as metaphor can be expressed as follows: End of an era and beginning of another era, paradigm shifts, political instability, existential crises, social and economic chaos, demographic mobility, immigration, and diaspora, anarchy and acts of terrorism, illegal strategies, Carl Schmitt effect as legalization of totalitarianism, relativity of

i Correspondence: email simber.atay@gmail.com 
conventional moral values, uncertainty, intuitive and eerie details of everyday life, cosmopolitanism, melancholy, passionate, intense, euphoric experiences, auto-destructive lives, suspended lives, breathless lives and immense artistic creativity. Each" beginning of the end" era is a becoming process. However, as of recent history, roughly, the period between the fall of the Austro-Hungarian Empire, World War I, the establishment of the Weimar Republic in 1919 and the coming to power of Reich III in 1933 and World War II is one of the most decisive "beginning of the end" periods. Holocaust was the end. Millions of people died in Nazi concentration and extermination camps. As far as it goes neither Europe, nor the world recovered after that. Eventually, this historical "beginning of the end" has become globally an important vital, cultural, and political experience, and it has maintained its quality in the following periods, and it still does today.

"The beginning of the end" is also a question of aesthetic sensibility and an environment of artistic creativity. In this regard, for instance, the cultural heritage and avant-garde creativity of the Weimar Republic, from literature to photography, from cinema to music, from visual arts to plastic arts, are still influential (Freund, 1976:97). Thus, today, we can easily talk about the existence of a "beginning of the end" aesthetic. Therefore, artists can create works that spontaneously fall into this category during "the beginning of the end" period and develop specific creative strategies or they can personally represent this category. Sometimes, some artists live romantically as the protagonist of the "beginning of the end", mutually confirming their lives with their art and their lives with their art. Thus, "the beginning of the end" becomes an artistic leit-motiv, and, a dramatic design for art works.

In this study, the "beginning of the end" phenomenon was developed, especially based on the period mentioned above, articulating some figures as Joseph Roth, Roman Vishniac, László Nemes Joseph Losey and Alain Delon by their related works.

Joseph Roth writes about "the beginning of the end", Roman Vishniac takes photos of this situation, László Nemes is a researcher of the same subject. As for Alain Delon, he performs the role of a "beginning of the end" protagonist in Joseph Losey's movie Mr. Klein.

Again, in this sense Joseph Losey's Mr. Klein (1976) is a modern cinema classic. Robert Klein is a hero who has chosen his fate in a historical and individual beginning of the end process; free-will and courage at stake here are not special virtues, but authentic characteristics. Therefore, he represents an example of pure redemption.

\section{The Beginning of the End}

Famous poet, critic and author of magnificent Causeries du lundi (Monday Chats, 1849-1869) Charles-Augustin Sainte-Beuve (1804-1969) wrote also the biography of Charles-Maurice de Talleyrand-Périgord. In this biography entitled Monsieur de Talleyrand, Saint-Beuve (1870) elaborates on the issue as follows: "Les événements de 1814 approchaient; à l'annonce du désastre de 1812, Talleyrand avait dit le mot décisif: "Voilà le commencement de la fin.» La fin prévue se précipitait." / "The events of 1814 were approaching; on the announcement of the disaster of 1812, Talleyrand had said the decisive word: "Here is the beginning of the end." The expected end was rushing" (p.112).

The disaster of 1812 is Napoléon Bonaparte's expedition to Russia that ended in a terrible defeat and consequently the events of 1814 were the invasion of Paris by coalition forces of 
Prussians, Austrians, Russians and abdication and exile of Napoléon Bonaparte Hence Charles Maurice de Talleyrand, the legendary name of diplomacy history and the foreign minister of Napoléon Bonaparte, defined the final of Bonaparte's rule and the First Empire in the same way. After that, Napoléon Bonaparte would return to Europe in 1815, but would again be defeated at the Battle of Waterloo and died in 1821 - again in exile, this time on the island of Sainte-HélèneThe period in question was likewise a chaotic one for France and whole Europe.

This statement of Talleyrand as "the beginning of the end" is a decisive historical definition and has become a popular motto over time. Moreover, in terms of aesthetic creativity, "the beginning of the end" became a question of art language, a genre. Eventually original "the beginning of the end protagonist" was Napoléon Bonaparte. However, there are many and various "the beginning of the end" protagonists in history and in art environment.

\subsection{Joseph Roth (1894-1939)}

He is personally a typical protagonist of "the beginning of the end" and tells the stories of people who live in the same context. His entire work is a chronotopia of beginning of the end which has been realized between World War I and World War II. He is one of the most vagabond but bienorganisé souls who defined the cultural panorama of the 20th century.

He witnessed the fall of the Austro- Hungarian Empire and then worked in Berlin during the Weimar Republic period which was also a beginning of the end process. Roth has a sophisticated sense of humor. His works, which are among the classics of modern European and German Literature, are still read with pleasure today. His author identity is synthesis of journalist and novelist identities. For this reason, his style is fluid and transparent. Thus, according to Yudkin (2011): "The author can be both his own created character as well as a detached onlooker. He can also sometimes act as the omniscient narrator" (p.127).

Roth was a bohemian, very generous and beloved person among his friends (Zweig, 2018: 11). But unfortunately, his life was very dramatic and especially toward the end was almost an agony representation. It can be stated that the reasons for this individual and collective situation are as follows: the cultural collapse and wreckage of the Austro-Hungarian Empire that he admired, believed, and was a part of; the fate of Eastern European Jews trying to survive an endless process of marginalization and the mental illness of his beloved wife suffering from schizophrenia.

Roth was born in Brody-East Galicia, attended university in Vienna. As it is understood from his books, he knows his country closely and after its breakup, he missed always the Imperial order of this magnificent, multilingual, and multicultural social organization. The book Radetzkymarch, first published in 1932, represents this deep nostalgia as the following conversation suggests:

\section{Count Chojnicki: "We are no longer living."}

Baron Trotta: "I don't understand! Why do you think the monarchy no longer exists?"

Count Chojnicki: "Yes, we officially exist! ... "We have an army! ... We also have officers!" ... But this living body of the monarchy is slowly decomposing... The era does not want us anymore! The era wants to create free nation-states! ... New religion, nationalism! ... God cannot leave the emperor of Austria-Hungary. But now God left him alone" (Roth, 2019: 201-202). 
According to Stephen Zweig (2018): "Those who want to know what the monarchy wrote on the tombstone is enough to mix the pages of this book, Radetzkymarsch / Radetzky March (1932) and Die Kapuzinergruft / The Capuchin Tomb (1938)" (p.13).

III. The Reich is not only a change of political power, but the gradual transformation of the entire German society into a corrupt, homogeneous, opportunist society. This moral transformation was identified very early by Roth and described in Das Spinnennetz / The Spider's Web (1923). Theodor Lohse, one of the characters of the novel is a figure representing this transformation: "He was the European young man. Nationalist and selfish, unbeliever and unfaithful, bloodthirsty, and retarded... That was "Young Europe" ..." (Roth, 2011: 81).

After III. Reich came to power, as happened to many other writers, Joseph Roth's books were also banned and burned. He foresaw this disaster and wrote to his close friend Stephen Zweig, and states as follows: "I think you are aware that we are dragged into a terrible disaster. Our literary life will disappear..." (Cited by Arpad, 2019: 10). On the other hand, Roth has often described the effort to survive during this difficult period; as an example in this context: The protagonist of the story entitled A Letter Came This Morning... (1935-1936), receives a letter from his friend Naphtali Kroj one day, and on this occasion, he remembers his native land and deep longing, this time in Russia: "The place where I was born is no longer on any map, no place is my home. It's both strange and terrible. I'm like a dream; a dream that has no root, no goal, no beginning, no end, and comes and goes without knowing where it came from and where it went. People from my hometown always live like this. They are scattered in every aspect of the world, in its infinity" (Roth, 2014:218).

Another book of Roth titled Juden auf Wanderschaft /The Wandering Jews (1927) is a typology on the Jews of Eastern Europe. Roth described their difficult living conditions, the differences in mentality between them and the Jews of Western Europe, their several problems in detail with his objective and sincere style, as a deterritorialization logbook. In the "Jewish quarters of the West" section of the text, he describes the ghettos in Vienna, Berlin and Paris; his following definition of life in Berlin summarizes the situation of these people: "Around here, people tend to do what they want. Those who gather pray, stop in the middle of the street, and start negotiating. Daily life always resembles Exodus from Egypt! Something can happen anytime, anywhere...they may need to be put on the road again" (Roth, 2018:71).

Roth also examined the situation in the Soviet Union and the Eastern European Jews who immigrated to the United States. However, official rejection of anti-Semitism in Russia or reterritorialization possibilities in USA (Roth, 2018: 99) are not enough to solve the problem of marginalization of Jews that means the uncertainty of their situation was chronic.

Roth (2018), in the same text, evaluates the cultural meaning and profundity that Eastern European Jews have brought to German Language and Literature, and he underlines as follows: "For the Eastern Jew, Germany is still the country of Goethe and Schiller. Every Jewish teenager who loves to read and learn gets to know them better than a swastika lover German high school student" (p.9).

Unfortunately, the last years of Roth's life are like a suicidal process. He was a heavy drinker and a smoker. However, he also has an extraordinarily productive performance as a journalist and writer again in the same period. According to Stephen Zweig (2018); " The fact that his soul was able to remain alive while his body collapsed is against all the laws of thought and medicine, and therefore it is a miracle!" (p. 17). Roth's wife, Friederike Reichler, was also "exterminated" in 1940, a year after the author's death (1939), as part of Reich III's eugenics program." (no author, 2004). 


\subsection{Roman Vishniac (1897-1990)}

Roman Vishniac was born in Saint Petersburg and emigrated to Berlin in 1920 and finally settled in New York in 1940. His real profession is biologist. He also occupies an exceptional place in the History of Photography with his scientific photography works (Radzyner \& Barker, 2018) especially in the field of biology and zoology, such as macrophotography and time-lapse photography as well social-documentary photography.

"In 1935, he was hired by the American Jewish Joint Distribution Committee (JDC) - the world's largest Jewish relief organization - to photograph impoverished Jewish communities in Central and Eastern Europe as part of the organization's effort to raise funds and support" (No Author, 2016). Thus, he worked in Eastern and Central Europe, Poland, Romania, Czechoslovakia, Hungary, and Lithuania between 1935 and 1938 and he photographed ghettos. Thus, he became an extraordinary witness to this beginning of the end period that will end in the Nazi concentration and extermination camps. Vishniac has documented in detail the entire condition of the Jews, the places and environments where they lived and worked and their daily life activities. Some of these photographs were published in 1947 as an album with the title A Vanished World.

A Vanished World can be considered as a certain photographical equivalent of Joseph Roth's The Wandering Jews.

Alfredo De Paz (1988) describes the importance of this work as follows: "With the affected and fraternal participation of a co-religionist, Vishniac delivered, to the memory of all, sixteen thousand photographs (of which only two thousand remained) constituting the extreme gaze (and impotent for not having been able to do anything to save them) on some of those six million human beings that the Nazi fury would soon barbarously annihilate (in the ghettos with weapons and in the extermination camps through the gas chambers)" (p.248-249).

Vishniac's historical photo-records create mnemonic environments where the residual absence of victims becomes evidence of their eternal existence. These streets, dim interiors, these people, children posing cheerfully, beggars, peddlers, sad old people, Talmud students, this extreme poverty, this collective loneliness, this innocence, all this life is now only present in Vishniac's photographs. This variation of punctum that exists in these photographs is pure representation of Time as Roland Barthes defined in Camera Lucida (1981:96) and in this connection, life and death are synchronized and equalized. As emphasized by Roland Barthes, again (1981): "I read at the same time: This will be, and this has been observed with horror an anterior future of which death is the stake... This punctum, more or less blurred beneath the abundance and the disparity of contemporary photographs, is vividly legible in historical photographs: there is always a defeat of Time in them: that is dead and that is going to die" (p.96).

\subsection{László Nemes (1977)}

László Nemes is one of the most important and successful film directors of our time. His two feature films, Son of Saul (2015) and Sunset (2018) have won many international awards. Nemes has an intuitive cinema that means he does not give much explanation about the protagonists, hence there are many ambiguous details in his films.

Nemes inspired by the beginning of the end phenomenon in these both films; moreover, he takes the subject to a very difficult and delicate point and searches for answers to the following questions: What will happen if this phenomenon has come to its absolute end or can we still talk 
about existential responsibilities of human being in this point or is there still possibility of redemption?

\subsection{Son of Saul (2015)}

The film has won several awards, most notably the Grand Prix at the 2015 Cannes Film Festival and the Golden Globe Best Foreign Language Film, and the Oscar (88th Academy Awards) for the Best Foreign Language Film.

The film tells the events of two days in the crematorium, at Auschwitz Extermination Camp. Saul Ausländer (Géza Röhrig), a Hungarian prisoner and member of the Sonderkommando, witnesses the murder of a young boy who miraculously survived in the gas chamber, by doctor on duty there. After this incident, Saul has an impossible goal of saving the boy's body, finding a rabbi, and burying him. This self-burdened responsibility becomes his raison d'être. More clearly, Auschwitz is the absolute end and even at this point Saul has not forgotten the death ritual. Thence, he, on his own, saves the honor of whole humanity.

Mátyás Erdély is cinematographer of this film. He performs shallow focus as the principal visual strategy during film, especially in crematorium scenes and in this way, cinematography of this film becomes an existentialist morale code as an expression of respect for the victims of Auschwitz.

\subsection{Sunset (2018)}

The film premiered at the 75th Venice International Film Festival and won the Beijing International Film Festival 2019 best director and best film awards.

The film is set in Budapest in 1913. A young lady, named Irisz Leiter (Juli Jakab) returns to Budapest to work as milliner at the famous Leiter hat store that belonged to her parents once upon a time but now has a new owner. However, Irisz continues to stay and work there despite the many uncertainties of her situation. In fact, there are very few clues about Irisz. Meanwhile some intensive preparations are underway for very important imperial guests in the store. By the way, a stranger comes to Irisz and he tells her he is looking for her brother Kálmán Leiter who is probably an anarchist. Following this clue, Irisz goes out in the dark streets of Budapest and there, in a chaotic atmosphere she starts looking for Kálmán.

The fall of the Austro-Hungarian Empire and consequently World War I start the beginning of the end process. Irisz experiences this process in her own way. Moreover, her past is lost, her future is uncertain. Then, in the surprise finale of the film, Irisz is fighting as a soldier at the front in a trench. But this is an eerie battlefield because there is only Irisz, nobody else in sight. Then, instantly, it is passed from dramatic dimension to conceptual dimension because she has chosen to fight silently, without dispute, solo, and her struggle is the noema of human existence, both for herself and for all other people.

The cinematographer of Sunset is once again Mátyás Erdély. The atmosphere of the movie is mysterious because Nemes does not make conventional dramatic statements, instead he prefers to describe all this ambiguity by close-up portrait shots of Irisz. In this context, shallow focus aesthetic is dominant eventually. Likewise, the film is based chromatically on soft daylight and pastel colors. 


\subsection{Alain Delon (1935)}

Alain Delon made many cult films during his long and fruitful acting career. In his films, he is often the protagonist of "the beginning of the end" stories. Delon himself ironically makes the following statement: "I died practically in all my films" (Cited in Neuhoff, 2012:3). Hence, in the 1960s and 1970s, he often played the roles of hitman, thief, killer, fugitive, robber etc. But these criminal characters were always alone and destined to die at the end. In addition, this situation was already known to the audience that means a perfect catharsis possibility. Moreover, no matter what he did, he was unconditionally loved by millions of spectators, and was embraced cordially as an anti-system figure, a rebel. Eventually his sublime beauty and elegance played an important role in this mass- seduction. Even in those years, as a Zeitgeist phenomenon, the audience of cinema who desired radical/socialist social changes, idolized this transgressive outsider in some geography - for example in Turkey. Finally, Alain Delon is one of the last stars in the classical sense and has already a mythological position in the history of cinema.

\subsection{Joseph Losey's Mr. Klein (1976)}

Joseph Losey's film, Mr. Klein won 1977 César Awards for best director, best film, and best production design (Alain Delon was also nominee for best actor) and it's the second collaboration of Losey and Delon, after The Assassination of Trotsky (1972). Alain Delon is also producer of film.

Joseph Losey (1909-1984) is socially an upper class American, culturally a distinguished intellectual, politically a communist, and a sympathetic to Franklin D. Roosevelt's New Deal policies; then he was blacklisted and exiled by the McCarthy regime (Phillips, 1999:195). Following this situation, he worked continuously in Europe. He was very close in context of artistic formation to Bertolt Brecht and Sergei Eisenstein. Therefore, he has avant-garde sensibilities as well as Baroque gusto. In his films, Losey often told the stories of individuals who had been damaged by social class differences or bad coincidences. As Deleuze (1984) pointed out: "What appears first in Losey, is a very particular violence that impregnates or fills the characters ... It is a violence that is not only internal or innate, but static, whose equivalent is not found in Bacon in painting, when it evokes an "emanation" emanating from an immobile character, or in Jean Genet in literature" (162-163).

Mr. Klein is about The Vélodrome d'Hiver/Vél d'Hiv Roundup events of July 16-17, 1942. During these events, the police of the Nazi collaborator Vichy Régime arrested 13,152 Jews in Paris, one third of them children, and kept 8000 of them under terrible conditions, without food or water at Vélodrome d'Hiver. The rest were sent to another internment camp, then everyone was gathered at Drancy and deported to Auschwitz-Birkenau (Paolini, 2017).

Mr. Klein's story begins in January 1942. Robert Klein (Alain Delon), is a self-confident, rich, young, and handsome man living in Paris. His profession is art dealer. He has a nonchalant life, but he is also an opportunist person who makes great profit by buying works of art owned by Jews in need at cheap prices. One day, a Jewish newspaper is sent to his home. In that way, he learns that there is another Robert Klein living in Paris. Over time, due to this name resemblance, life begins to get more and more difficult in the anti-Semite environment of Paris. Thus, he begins to investigate the other Mr. Klein but he fails; and the situation becomes even 
more uncertain. Finally, Mr. Klein joins the Jews at The Vélodrome d'Hiver / Vél d'Hiv Roundup and spontaneously jumps into one of the trucks with them to Auschwitz.

"This sacrifice- Klein dies for having assumed this false identity-gives meaning to his life and transfigures it" (Jullier \& Leveratto, 2017:39)

On the other hand, choice of Mr. Klein and his fateful partnership with the Jews, is a naturalistic situation, an impulse-image phenomenon in Deleuzian context. According to Deleuze (1984):

"The character trembles on himself, himself prey to the violence of the impulse, and it is in this sense that he becomes the prey victim of his own impulse. Losey thus sets traps that are so many psychological contradictions within his work...The characters of Losey are not hard fakes but feeble fakes, condemned in advance by the violence that is in them and that pushes them to go to the limit of an environment that the impulse explores, but at the cost of making them disappear with their environment. More than all of Losey's other films, Mr. Klein is an example of a becoming that treats us to the trap of psychological or psychoanalytic interpretations .... This is exactly the becoming-Jewish of a non-Jew." (pp. 164-165).

This impulse-image phenomenon as a visual category, has two basic components: an original world and an elementary impulse. Original world means given environment, and it also means radical beginning and absolute end. In this regard, impulse is an impression (Deleuze, 1984:148-149).

The becoming other Mr. Klein of Mr. Klein or identification of these two Mr. Klein is important to Gilles Deleuze's philosophy because the film is also a story of "becoming". Deleuze, while reviewing Mr. Klein, also mentions Alain Delon: "Alain Delon has this static violence necessary for the Losey actor" (p.164).

Brown (1998) elaborates on a similar issue stating as follows: "One must, furthermore, thoroughly admire the performance of Alain Delon as he creates a character making every attempt to maintain composure on an impossibly pretty face while moving inexorably into the depths, whether of despair, self-destruction, or self sacrifice - or all of the above - we will never know" (p.83).

In that point, there is the beginning of a true historical end, due to the dramatic nature of the film and the characteristics of the Deleuzeian original world which is the active element of its cinematographic design. The protagonist individualizes this process, starting from the breaking point created by the identity debate and search until Vél d'Hiv.

Joseph Losey himself has the following explanation: "I have since about 1930, seen life as a dialectic progression between contradictions. The invasion of one kind of life by another kind of life is a sort of contradiction which produces a further and different synthesis" (Cited by Gardner, 2004:5).

\section{Conclusion}

"The beginning of the end" is a modern phenomenon. Historically, there have been many "the beginning of the end" experiences after Napoleon Bonaparte. However, especially the period 
between the fall of the Austro-Hungarian Empire and Auschwitz keeps its importance also in Post-Truth Age, because there are intense similarities between the political, and cultural dynamics of the period in question and the Post-Truth Era that's scene of several nihilist performances that manipulate and distort the reality of the present and the past.

At the same time, "the beginning of the end" is an artistic design model, and a powerful theme with many art branches, especially in literature and cinema. Hence art works, literary works and films with the theme of "the beginning of the end" have the potential to strengthen not only aesthetic sensitivity but also cultural and political intuition and to energize the practice of criticism to understand what is going on. As Cicero (1862) mentioned in his De Oratore: "Historia vero testis temporum, lux veritatis, vita memoriae, magistra vitae" (History is indeed the witness of the times, the light of truth, the life of memory, the teacher of life) (II 9.36; p.110).

\section{Note}

Joseph Roth quotations in the text have been translated from Turkish to English; Gilles Deleuze quotations in the text have been translated from Italian to English; Alfredo De Paz quotations in the text have been translated from Italian to English. Translations were made by me.

\section{Conflict of Interest Statement}

The author declares no conflicts of interests.

\section{About the Author}

Prof. Dr. Simber Atay is the head of the Photography Department at Dokuz Eylül University, Faculty of Fine Arts. Her research interests: Theories of Photography, Contemporary Cinema, Cyber Culture and Philosophy of Distance Learning.

\section{References}

Arpad, A. (2019). "Joseph Roth was a person who had great enthusiasm and pushed his limits” in Joseph Roth's Emperors Cemetery (Die Kapuzinergruft), (Trans. A. Arpad), Istanbul: Tekin.

Barthes, R. (1981). Camera Lucida Reflections on Photography, (Trans. R. Howard), New York: Hill and Wang.

Brown, R. S. (1998). “Mr. Klein by Joseph Losey”, Cinéaste, 24 (1), 82-83.

Cicero (1862). De Oratore, Leipzig: Druck und Verlag von B. G. Teubner https://archive.org/details/deoratore00pidegoog/page/n178/mode/2up?q=Historia+ +

De Paz, A. (1986). L'immagine fotografica Storia, estetica, ideologie, Bologna: Clueb.

Deleuze, G. (1984). L'immagine-movimento, (Trans. J.P. Manganaro), Milano: Ubulibri.

Freund, G. (1976). Fotografia e Società, (Trans. L. Lovisetti Fuà, Torino: Giulio Einaudi.

Gardner, C. (2004). Joseph Losey, Manchester \&New York: Manchester University Press.

Jullier, L. \& Leveratto, J. M. (2017). Delon and Performance: Emploi and the Interaction Between Individual, Role, and Character, In N. Rees -Roberts \& D. Wandron (Eds.), Alain Delon, Style, Stardom and Masculinity, (31-42), New York \& London: Bloomsbury Academic. 
Neuhoff, E. (03/01/2020). “Alain Delon: Je suis mort dans presque tous mes films". Retrieved from https://www.lefigaro.fr/cinema/2012/01/03/03002-20120103ARTFIG00560-alaindelon-je-suis-mort-dans-presque-tous-mes-films.php.

No Author (January 12, 2004) European Dreams Rediscovering Joseph Roth. https://www.newyorker.com/magazine/2004/01/19/european-dreams.

No Author (Feb 11, 2016- May 30, 2016). "Roman Vishniac Rediscovered", The Contemporary Jewish Museum https://www.thecjm.org/exhibitions/8.

Paolini, E. (2017). "La rafle du Vél' d'Hiv', symbole de la collaboration avec le régime nazi", Retrieved from https://www.lefigaro.fr/histoire/2017/07/16/2600120170716ARTFIG00009-la-rafle-du-vel-d-hiv-symbole-de-la-collaboration-avec-leregime-nazi.php.

Phillips, G. D. (1999). Major Film Directors of the American and British Cinema, Bethlehem: Lehigh University Press.

Radziner, H. J. \& Barker, J. B. (no date), “Illuminating Roman Vishniac: A Career in Biological Photography and Cinematography" Retrieved https://journals.uic.edu/ojs/index.php/jbc/article/view/9201/7508

Roth, J. (2011). Spider Web (Das Spinnennetz), (Trans. Betül Önal), Ankara: Kyrhos.

Roth, J. (2014). “A Letter Has Arrived This Morning” in Blind Mirror (Die Erzälungen), (Trans: A. Arpad), Istanbul: Can.

Roth, J. (2018). Jews on the Roads (Juden auf Wanderschaft), (Trans: A.Arpad), Istanbul: Kirmiz1 Kedi.

Roth, J. (2019). Radetzky Anthem (Radetzkymarsch), (Trans. A. Arpad), Istanbul: Can.

Saint-Beuve, C. A. (1870). Monsieur de Talleyrand, Paris: Michel Lévy Frères https://archive.org/stream/monsieurdetalley00sainuoft?ref=ol\#page/112/mode/2up/searc h/fin+de+commencement

Yudkin, L. I. (2011). "Joseph Roth (1894-1939): Between Reportage and Fiction", Revue Européenne des Études Hébraïques, No. 16 (2011), pp. 127-148, https://www.jstor.org/stable/2363195

Zweig, S. (2018). “Önsöz /Preface” in Joseph Roth's Hotel Savoy, (Trans. A. Arpad), İstanbul: Everest. 
Creative Commons licensing terms

Author(s) will retain the copyright of their published articles agreeing that a Creative Commons Attribution 4.0 International License (CC BY 4.0) terms will be applied to their work. Under the terms of this license, no permission is required from the author(s) or publisher for members of the community to copy, distribute, transmit or adapt the article content, providing a proper, prominent and unambiguous attribution to the authors in a manner that makes clear that the materials are being reused under permission of a Creative Commons License. Views, opinions and conclusions expressed in this research article are views, opinions and conclusions of the author(s). and European Journal of Literature, Language and Linguistics Studies shall not be responsible or answerable for any loss, damage or liability caused in relation to/arising out of conflicts of interest, copyright violations and inappropriate or inaccurate use of any kind content related or integrated into the research work. All the published works are meeting the Open Access Publishing requirements and can be freely accessed, shared, modified, distributed and used in educational, commercial and non-commercial purposes under a Creative Commons Attribution 4.0 International License (CC BY 4.0). 